\title{
Analysis of Ki67, HMGA1, MDM2, and RB expression in nonfunctioning pituitary adenomas
}

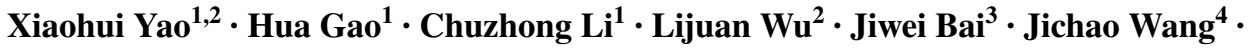 \\ Yangfang $\mathrm{Li}^{1} \cdot$ Yazhuo Zhang ${ }^{1}$
}

Received: 6 June 2016 / Accepted: 23 December 2016 / Published online: 2 March 2017

(C) The Author(s) 2017. This article is published with open access at Springerlink.com

\begin{abstract}
Nonfunctioning pituitary adenomas (NFPAs) are the most prevalent type of pituitary macro-adenoma. Clarifying the relationship between NFPA markers and disease progression or recurrence could provide a basis for administration of adjuvant treatments. The present study examined the expression levels of high-mobility group (HMG)A1, Ki-67, mouse double minute 2 homolog (MDM2), and retinoblastoma (RB)with respect to NFPA recurrence. Immunohistochemistry was carried out using antibodies to Ki-67, MDM2, HMGA-1, and RB on tissue microarray slides of a cohort of 35 paired NFPA samples of primary and recurrence/regrowth tumors. Based on postoperative magnetic resonance imaging data, tumors were classified as recurrence $(\mathrm{n}=20)$ included primary and recurrent tumors or regrowth $(\mathrm{n}=15)$ included primary and regrowth tumors, which are paired. Protein expression was classified as negative or positive according to the $\mathrm{H}$-score method and was analyzed with respect to clinical and pathological findings. MDM2-positive cases accounted for $11 / 20$ primary and $19 / 20 \mathrm{~s}$ recurrent tumors $\left(\chi^{2}=8.533\right.$, $\mathrm{P}=0.003$ ), and $9 / 15$ primary tumors and $15 / 15 \mathrm{~s}$ regrowth tumors $\left(\chi^{2}=7.5, \mathrm{P}=0.006\right)$. MGA1-positive cases represented $9 / 20$ primary tumors and $16 / 20 \mathrm{~s}$ recurrent tumors
\end{abstract}

Yazhuo Zhang

zyz2004520@yeah.net

1 Key Laboratory of Central Nervous System Injury Research, Beijing Neurosurgical Institute, Capital Medical University, Tiantanxili 6\#, Beijing 100050, China

2 Shanxi Provincial People's Hospital, Taiyuan, Shanxi, China

3 Neurosurgical Department, Beijing Tiantan Hospital, Beijing, China

4 Department of Neurosurgery, Xinjiang Uygur Autonomous Region People's Hospital, Xinjiang, China $\left(\chi^{2}=5.227, \mathrm{P}=0.022\right)$, and $4 / 15$ primary tumors and $12 / 15$ s regrowth tumors $\left(\chi^{2}=8.571, P=0.003\right)$. There was no statistically significant difference in Ki-67 expression between primary and second recurrent/regrowth tumors although theKi67 labeling index was higher in the latter groups. RB was highly expressed in all groups with no significant difference between them. HMGA1 and MDM2 were more highly expressed in recurrence/regrowth cases of NFPA than in primary NFPA. HMGA1 and MDM2 are biomarkers and potential drug targets for NFPA treatment.

Keywords Nonfunctioning pituitary adenoma $\cdot$ Tissue microarray $\cdot$ Recurrence $\cdot$ Regrowth $\cdot$ HMGA1 $\cdot$ MDM2

\section{Background}

Nonfunctioning pituitary adenomas (NFPAs) are the most prevalent type of pituitary macroadenoma, accounting for $25-35 \%$ of all cases [1]. Although they are generally benign, many invade the sphenoid, cavernous sinus, or dura mater and may be incompletely removed by surgical resection. The remnant tumor can potentially regrow since residual cells retain their ability to proliferate, necessitating a second therapeutic intervention [2]. Most cases of recurrence occur within 5 years after surgery [3]. Owing to the high rate of long-term recurrence, patient prognosis is not always favorable [4]. The main therapeutic option for NFPA is surgical and there are currently no pharmacologic treatments available. A variety of histological biomarkers for NFPA have been investigated for their relationship to invasiveness and tumor recurrence, including the proliferation marker $\mathrm{Ki}-67$, cellcycle-related factors such as p27 and galectin-3, and other molecules such as p53,O6-methylguanine-DNA methyltransferase, and matrix 
metalloproteinase 9 [5-7]. However, given the absence of reliable serum markers for detecting residual tumor cells, the decision on whether to recommend additional intervention is typically made based on postoperative imaging.

The high-mobility group (HMG)A family of proteins has four members; one of these, HMGA1, plays a critical role in cancer progression, development, and metabolism, among others [8]. HMGA proteins are expressed at low levels in normal adult tissues and cells, but is upregulated in many tumors, neoplastically transformed cells, and embryonic stem cells [9]. HMGA overexpression is associated with poor prognosis due to metastasis [10]. HMGA1 has been linked to pituitary tumor progression, consistent with its critical role in cell cycle regulation [11]. HMGA2 is associated with the retinoblastoma (RB)-E2F pathway in pituitary cell proliferation [12]; RB protein is also involved in cell cycle control. Unlike HMGA2, the role of HMGA1 in pituitary tumorigenesis remains poorly understood. The expression of HMGA1 suggests a link to a secondary event in pituitary gland tumorigenesis [11].

Mouse double minute 2 homolog (MDM2) plays a critical role in the regulation of the tumor suppressor protein p53 [13]; MDM2 overexpression inhibits p53 activation, leading to evasion of the cell cycle checkpoint and carcinogenesis $[14,15]$; it is also overexpressed in many human malignancies [16]. Ki-67 is a reliable cell proliferation marker in immunohistochemistry (IHC) used to assess tumor progression in routine histological analyses [17]. Although it is routinely applied to pituitary adenomas, its prognostic significance remains controversial $[18,19]$.

Tissue microarrays (TMAs) are assembled from many tissue samples in a single paraffin block to increase the throughput and performance of molecular profiling studies in tumors, and can reduce experimental variables and conserve tissue samples. In this study we used TMAs to evaluate the expression of HMGA1, Ki-67, MDM2, and RB in 35 paired NFPA cases of primary and recurrent/regrowth tumors to identify a suitable marker for NFPA progression.

\section{Materials and methods}

\section{Patients}

This retrospective study included 35 patients at the Beijing Tiantan Hospital, Captital Medical University, who underwent transphenoidal or transcranial operation from January 2008 to December 2013.Tumors were all NFPAs according to the 2007 WHO histologic classification. According to Knosp classification and records of operation, NFPAs included non-invasive and invasive tumors (Table1). There were classified into recurrence group included primary and recurrenttumors which are paired and regrowth group included primary and regrowth tumors which are paired. Recurrence was diagnosed in 20 patients when a new tumor was histologically confirmed, Regrowth in 15 patients was diagnosed by the growth of a residual tumor, which was evaluated by a neurosurgeon and two neuroradiologists who were blinded to the patient's characteristics (see in Sheme 1). The study was carried out according to an institutional review board-approved protocol, and written; informed consent was obtained from all patients prior to surgery.

\section{TMA construction}

Formalin-fixed, paraffin-embedded tissue blocks were stained with hematoxylin and eosin (H\&E). Three core biopsies with a diameter of $2.0 \mathrm{~mm}$ were transferred to TMAs using the Leica BOND-III fully automated arrayer (Leica Biosystems, Wetzlar, Germany). The core samples were randomly ordered and the pathologist was blinded with respect to their location on the TMA slides. TMAs were cut into $4-\mu \mathrm{m}$ sections using a serial microtome and placed in a water bath at $50^{\circ} \mathrm{C}$; the sections were transferred to positively-charged glass slides, deparaffinized, and rehydrated through a graded series of alcohol with water as the final solution. Slides were dried at room temperature for $24-48 \mathrm{~h}$ and stored in a freezer at $-80^{\circ} \mathrm{C}$ until use. To minimize loss of antigenicity, sections were processed within 1 week of cutting [20].

\section{IHC}

Tumor content and quality were evaluated in TMA slides by H\&E staining. Antibodies against the following proteins were used under the indicated conditions: Ki67 (Abcam, Cambridge, UK), protocol F, with 20 min of epitope retrieval (ER) and $15 \mathrm{~min}$ of heat-induced epitope retrieval (HIRE); MDM2 (Abcam), with 3 min of ER and 30 min of HIRE; HMGA1 (1:3000; Abcam), with 20 min of ER and 15 min of HIRE; and RB (1:500; Abcam) with $30 \mathrm{~min}$ of ER and $30 \mathrm{~min}$ of HIRE. Bond Polymer Refine Detection (DS9800; Leica Biosystems) was used to detect the primary antibodies. The slides were scanned as digital images using Aperio AT2 (Leica Biosystems). The intensity of staining was calculated by two neuropathologists who were blinded to the patient's clinical and radiologic information.

\section{TMA scanning and image analysis}

Antigen labeling index (LI) was determined by counting the number of positive cells in a total of 1000 tumor 
Table 1 The patient characteristics of recurrence/ regrowth group

\begin{tabular}{|c|c|c|c|c|}
\hline \multirow[t]{2}{*}{ Feature } & \multicolumn{2}{|l|}{ Recurrence } & \multirow[b]{2}{*}{ Primary } & \multirow[b]{2}{*}{ Regrowth } \\
\hline & Primary & Recurrence & & \\
\hline Number & 20 & 20 & 15 & 15 \\
\hline \multicolumn{5}{|l|}{ Age (year) } \\
\hline Range & $20-57$ & $21-63$ & $21-59$ & $22-62$ \\
\hline Median & 37 & 41 & 38 & 41 \\
\hline Mean & 37.55 & 41.45 & 39.4 & 41.7 \\
\hline \multicolumn{5}{|l|}{ Sex } \\
\hline Male & 9 & 9 & 4 & 4 \\
\hline Female & 11 & 11 & 11 & 11 \\
\hline Head ache & 14 & 10 & 8 & 8 \\
\hline Diminution of vision & 12 & 8 & 11 & 7 \\
\hline Visual field defect & 7 & 4 & 6 & 7 \\
\hline Incidental/reexamine & 2 & 3 & 2 & 3 \\
\hline \multicolumn{5}{|l|}{ Knosp grading } \\
\hline Grade1 & 5 & 4 & 0 & 0 \\
\hline Grade2 & 7 & 9 & 5 & 3 \\
\hline Grade $3 a$ & 4 & 3 & 1 & 1 \\
\hline Grade $3 b$ & 4 & 1 & 2 & 3 \\
\hline Grade4 & 0 & 3 & 7 & 8 \\
\hline \multicolumn{5}{|l|}{ Invasive } \\
\hline Yes & 7 & 5 & 10 & 11 \\
\hline No & 13 & 15 & 5 & 4 \\
\hline \multicolumn{5}{|l|}{ Volume $\left(\mathrm{cm}^{3}\right)$} \\
\hline Range & $1.144-19.06$ & $2.700-21.00$ & $1.092-51.28$ & $1.825-36.52$ \\
\hline Median & 7.182 & 6.000 & 14.18 & 10.50 \\
\hline Mean & 8.540 & 7.637 & 16.46 & 12.92 \\
\hline \multicolumn{5}{|c|}{ Recurrence/regrowth time (m) } \\
\hline Range & & $10-68$ & & $6-58$ \\
\hline Median & & 35 & & 27 \\
\hline Mean & & 35.8 & & 25.4 \\
\hline
\end{tabular}

cells in the maximally stained region at high magnification $(400 \times)$. The staining intensity was stratified on a scale of $0-3 \quad(0=$ no staining, $1=$ weak, $2=$ moderate, and $3=$ strong). An $\mathrm{H}$-score was obtained by multiplying the staining intensity with a constant to adjust the mean to the strongest staining $[$ score $=1.0(\%$ weak $)+2.0(\%$ moderate $)+3.0(\%$ strong $)]$.

\section{Statistical analysis}

The $\chi^{2}$ test was used to assess the significance of associations among HMGA1, Ki67, MDM2, and RB expression and clinical parameters. Differences were considered statistically significant at $\mathrm{P}<0.05$. Analyses were carried out using SPSS v.19.0 software (IBM, Armonk, NY, USA).

\section{Results}

\section{Characteristics of the cohort}

We selected 35 consecutive patients diagnosed with NFPA for whom primary and recurrent; primary and regrowth tumor specimens were available, which are paired. Visual disturbance $(23 / 35,65.7 \%)$ was the most common clinic symptom, followed by headache $(22 / 35$, $62.8 \%$ ) and visual field deficits $(13 / 35,37.1 \%)$. Tumor recurrence was detected in 9 male and 11 female patients, with a mean recurrence time of 35.8 months (range: 10-68 months). Most patients (18/20, 90\%) experienced recurrence within 5 years, with a mean time of 32.4 months (range: 10-55 months). Tumor regrowth was observed in 4 male and 11 female patients, with a mean regrowth time of 25.4 months (range: 6-58 months). Patient characteristics are summarized in Table 1; there 


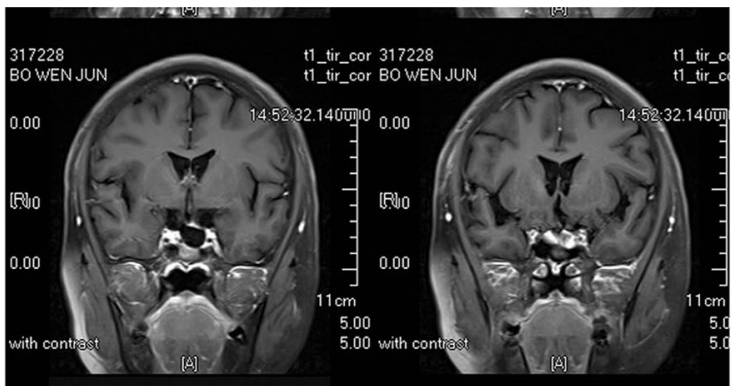

A

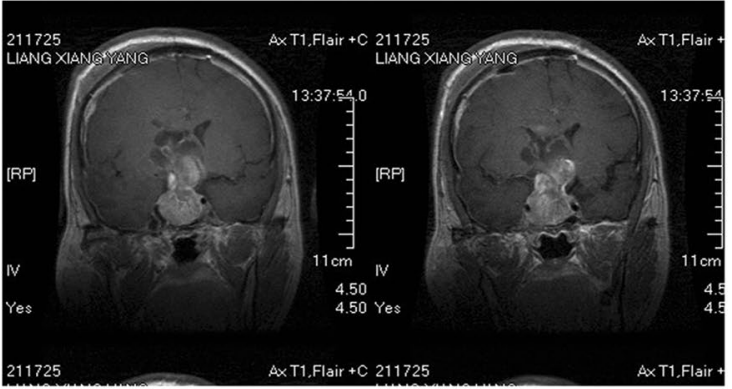

C

Scheme 1 a First postoperative MR image demonstrating complete tumor removal in a 30-year-old women. b MRI scan obtained 24 months after surgery shows a distinct tumor recurrence in the

was no difference found with respect to gender, age, tumor size, or invasion among groups.

\section{HMGA1, Ki67, MDM2, and RB expression in recurrent NFPA}

Samples were scored for nuclear expression of HMGA1, Ki67, MDM2 and RB. Of the 20 samples, nine were HMGA1-positive, with Hscores of 43.75 and 100 for primary and recurrent tumors, respectively $\left(\chi^{2}=5.227\right.$, $\mathrm{P}=0.022$; Fig. 1a, b). There were 11/20 MDM2-positive cases, with $\mathrm{H}$-scores of 65.45 and 170 for primary and recurrent tumors, respectively $\left(\chi^{2}=8.533, \mathrm{P}=0.003\right.$; Fig. 2a, b). There were no statistically significant differences in rates of $\mathrm{RB}$ positivity between the primary and recurrent tumor groups, although the $\mathrm{H}$-score was higher in the latter (Table 2).Ki-67 is a marker for proliferating cells in neoplastic lesions; the $\mathrm{Ki}-67 \mathrm{LI}$ was found to be in the range of $0-12.4 \%$ for moderate immunoreactivity $(2+)$, with mean values of 2.76 and $4.09 \%$ for primary and recurrent groups, respectively.

\section{HMGA1, Ki67, MDM2, and RB expression in regrowth NFPA}

Among the 15 cases of regrowth NFPA, four were HMGA1-positive with $\mathrm{H}$-scores of 16.84 and 76.67 for

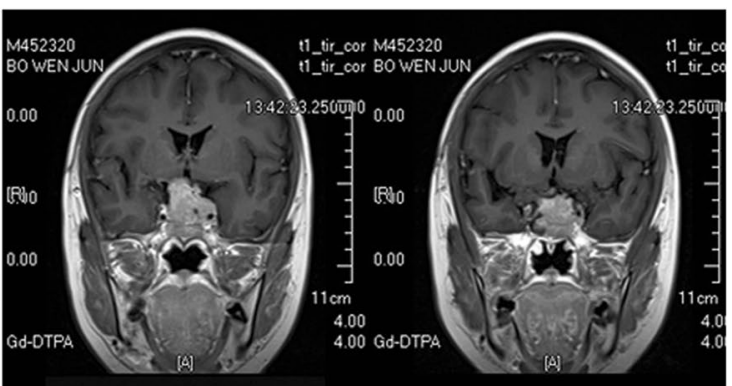

B

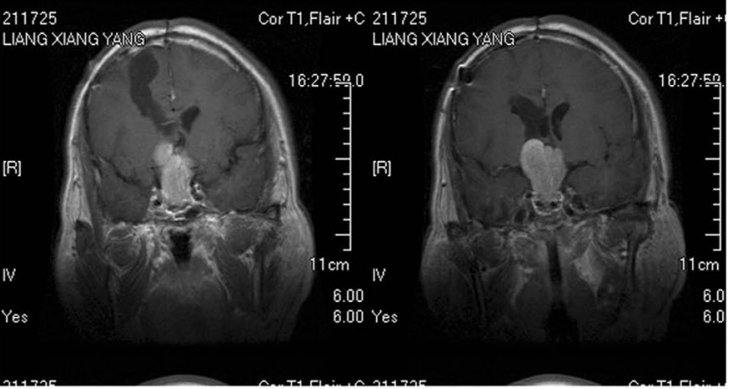

D

sellar. c First postoperative MR image demonstrating incomplete tumor removal in a 41-year-old men. d MRI scan obtained 58 months after surgery shows a distinct tumor regrowth in the sella

residual and regrowth tumors, respectively $\left(\chi^{2}=8.571\right.$, $\mathrm{P}=0.003$; Fig. 1c, d). There were nine MDM2-positive cases, with $\mathrm{H}$-scores of 71.58 and 146 for residual and regrowth tumors, respectively $\left(\chi^{2}=7.5, \mathrm{P}=0.006\right.$; Fig. $2 \mathrm{c}$, d). There was no statistically significant difference in the rates of RB positivity between the primary and regrowth tumor groups, although the $\mathrm{H}$-score was slightly higher in the latter (Table 3). The mean Ki-67 LI was 2.52 and 3.43 in the residual and regrowth groups, respectively. To assess the significance of HMGA1 and MDM2 over expression in NFPA, we examined the relationship between HMGA1 and MDM2 immunoreactivity and clinicopathologic features. There were no significant differences in terms of gender, age, tumor size, and invasion between primary tumor and recurrence/regrowth groups.

\section{Discussion}

Surgery is still the first and only treatment option for treating NFPA, and can rapidly improve clinical symptoms, including the headache, visual disturbance, and visual field deficits observed in this study. Visual disturbances due to compression of the optic apparatus are common, occurring in $30.8-67.8 \%$ of cases $[21,22]$, whereas visual field deficits related to compression of the optic chiasm are observed in $60.8 \%$ of patients [23]. The frequency of headaches 

of HMGA1. a In the primary tumor specimens. $\mathbf{b}$ In the recurrence tumor specimens. c In the residual tumor specimens. $\mathbf{d}$ In the regrowth tumor specimens. $\times 200$
Fig. 1 The expression level
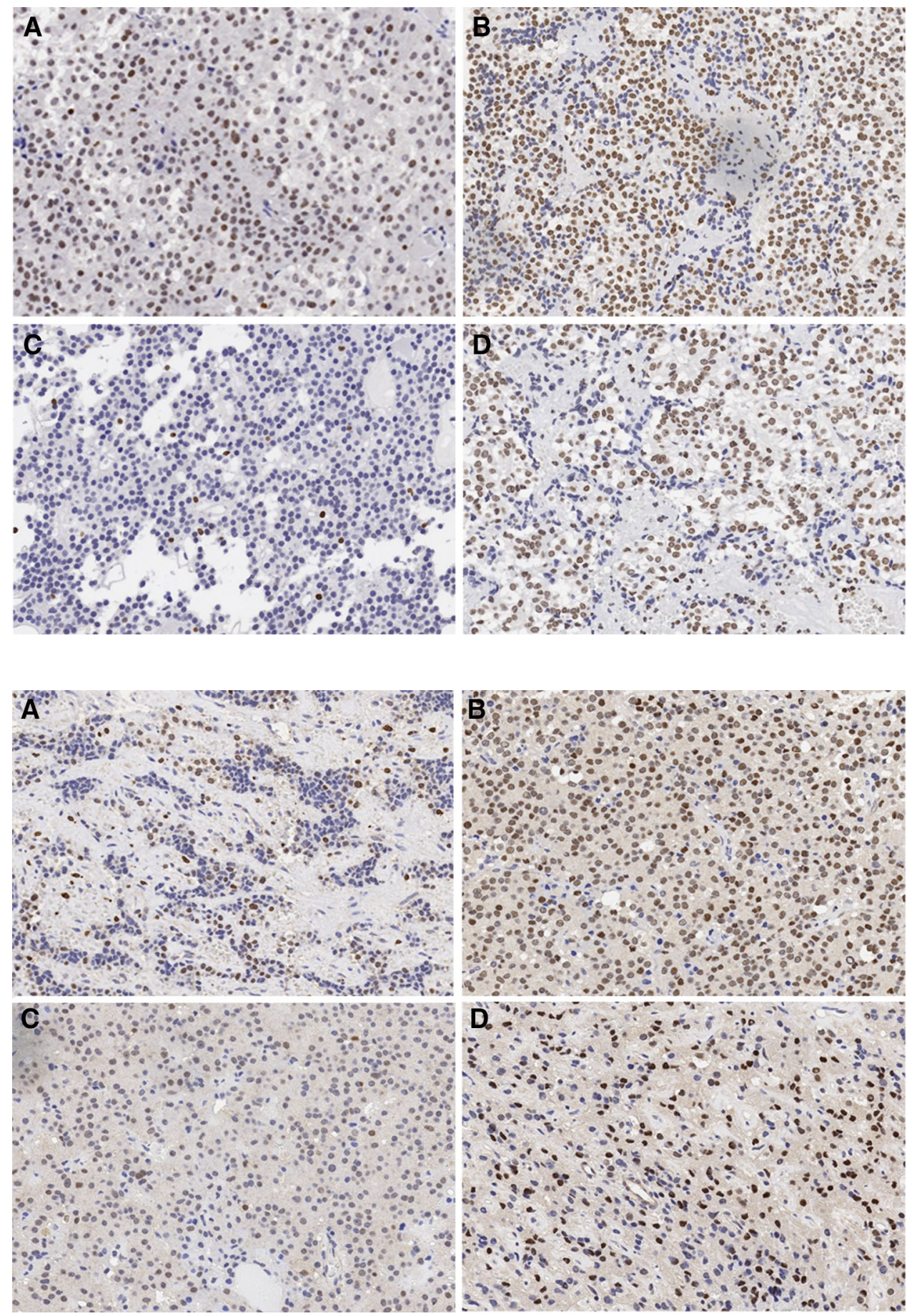

Fig. 2 The expression level of MDM2. a In the primary tumor specimens. b In the recurrence tumor specimens. $\mathbf{c}$ In the residual tumor specimens. d In the regrowth tumor specimens. $\times 200$

Table 2 The HMGA1, MDM2, Ki67 and RB level in recurrence group

\begin{tabular}{llllllllllllll}
\hline Gene & \multicolumn{3}{c}{ HMGA1 } & \multicolumn{3}{c}{ MDM2 } & \multicolumn{3}{c}{ Ki67 } & \multicolumn{1}{c}{ RB } \\
\hline Classification & $(-)$ & $(+)$ & H-Score & $(-)$ & $(+)$ & H-Score & $(-)$ & $(+)$ & H-Score & $(-)$ & $(+)$ & H-Score \\
Primary & 11 & 9 & 43.75 & 9 & 11 & 65.45 & 19 & 1 & 2.76 & 3 & 17 & 80.43 \\
Recurrence & 4 & 16 & 100 & 1 & 19 & 170 & 17 & 3 & 4.09 & 0 & 20 & 138 \\
\hline
\end{tabular}


Table 3 The HMGA1, MDM2,Ki67 and RB level in regrowth group

\begin{tabular}{llllllllllllll}
\hline Gene & \multicolumn{1}{c}{ HMGA1 } & \multicolumn{3}{c}{ MDM2 } & \multicolumn{3}{c}{ Ki67 } & \multicolumn{1}{c}{ RB } \\
\hline Classification & $(-)$ & $(+)$ & H-score & $(-)$ & $(+)$ & H-Score & $(-)$ & $(+)$ & H-Score & $(-)$ & $(+)$ & H-score \\
Residual & 11 & 4 & 16.84 & 6 & 9 & 71.58 & 14 & 1 & 2.52 & 1 & 14 & 91.05 \\
Regrowth & 3 & 12 & 76.67 & 0 & 15 & 146 & 14 & 1 & 3,43 & 1 & 14 & 126.7 \\
\hline
\end{tabular}

varies between 9.7 and $60.8 \%$ [21-23]. In our study, $90 \%$ of patients showed recurrence within 5 years, consistent with a previous report that the majority of cases show recurrence between 1 and 5 years after surgery [24].

This is the first study to compare the expression of Ki-67, MDM2, HMGA1, and RB in paired primary and recurrent/regrowth NFPA specimens. HMGA, MDM2, and $\mathrm{RB}$ regulate different points of the cell cycle and therefore play critical roles in pituitary cell proliferation and pituitary adenoma development. We found no difference in the levels of these proteins between the recurrence and regrowth groups, suggesting a higher risk associated with non-radical excision of recurrent adenoma. A microsurgical transsphenoidal approach was used in most patients in this study, which often does not include the whole medial cavernous sinus wall; therefore, patients should be closely monitored for tumor recurrence [25], although post-operative residual adenoma is not an independent predictor of recurrence [26]. Modern molecular genetic techniques have already exposed that a pituitary adenoma grow out of a single cell. So sometimes it is impossible for radical resection of some NFPAs in histological level, and the remnant tumor can potentially regrow since residual cells retain their ability to proliferate.

\section{Prognostic significance of HMGA1}

The HMGA protein family includes HMGA1 and the closely related HMGA2 protein, which are non-histone chromosomal proteins that target the minor groove of ATrich DNA strands through their adenine/thymine-binding motifs [27].HMGA overexpression is a feature of cancers of the colon, rectum, breast, pancreas, ovary, lung, esophagus, and testis, among others, and can be used to predict patient prognosis and drug response [28]. HMGA overexpression reflects the dysregulation of cell cycle-related proteins in pituitary adenomas and is associated with tumor invasion through interaction with the RB-E2F1 pathway [12]. It has been reported that HMGA proteins upregulate cyclin B2 expression, which is correlated with human pituitary tumorigenesis [29]. However, there is no obvious relationship between the HMGA-1 and tumor regrowth [30]. HMGA1 is a therapeutic target in pancreatic cancer [31]. Here we found that HMGA1 was upregulated in recurrent and regrowthtumors as compared to primary tumors, suggesting that it plays a significant role in NFPA progression.

\section{Prognostic significance of Ki-67}

Ki-67 is an immunohistochemical marker routinely used in pituitary adenomas, but its prognostic significance is debated [18]. Previous studies have reported Ki-67 positivity rates of 2.7-15\% [32-34]. Several studies have explored the possibility of using $\mathrm{Ki}-67$ as a prognostic marker of tumor recurrence or regrowth [30]. One study reported that tumorigenesis was correlated with a Ki-67 LI >2\% [40]; others have demonstrated that an LI $>2.2 \%$ was associated with residual tumor growth [30] or that an LI $>3 \%$ was a strong prognostic factor for pituitary adenoma recurrence/ progression [35]. However, some investigators have found no correlation between $\mathrm{Ki}-67$ expression and post-operative tumor behavior [36]. We found a Ki-67 LI of $0-12.4 \%$ associated with moderate staining intensity $(2+)$ with no difference between primary/residual and recurrent/regrowth adenomas. The elevated Ki-67 index revealed a strong tendency which suggests that Ki-67 plays some extent role in adenoma progression. Some authors had a similar conclusion. Micko revealed a strong tendency between invasive and non-invasive adenoma, and no statistically significant correlation to higher MIB-1 in invasive cases [37]. Indeed, there was no association between Ki-67 LI and Knosp classification, which were similar in adenomas with total and partial surgical removal [38].

\section{Prognostic significance of MDM2}

MDM2 is an oncogene that promotes tumor transformation, invasion, and metastasis in a p53-independent manner [39]. MDM2 negatively regulates p53 via various mechanisms such as cell cycle control, genome stability, apoptosis, and tumor neoangiogenesis by ubiquitination, transcription factor activation, and regulation of mRNA stability [40]. MDM2 is overexpressed in various human tumors, including sarcoma, leukemia, breast carcinoma, melanoma, and glioblastoma [41]. A recent study detected MDM2 nuclear expression in $21.3 \%$ of malignant pleural mesothelioma patients, which was correlated with worse prognosis [42]. The Nutlin analog RO5503781 targets the p53-binding site on MDM2 protein and increases its potency [43].In this study, MDM2 was detected in 55\% of primary and 95\% of recurrent NFPA specimens, while MDM2 positivity was observed in $60 \%$ of primaryand in $100 \%$ of regrowth specimens. The higher expression MDM2 in recurrent 
and regrowthtumors indicate an associated with NFPA progression.

\section{Prognostic significance of RB}

The RB tumor suppressor directly and indirectly modulates tumor development as a negative regulator of the cell cycle via interaction with members of the E2F family [44]. In fact, RB inhibits both cell cycle progression and apoptosis [45]. Although we found no difference in RB expression among groups, all specimens showed positive RB expression, suggesting that $\mathrm{RB}$ is involved in the development of NFPA.

\section{Conclusions}

In this study, we found that NFPA recurrence and regrowth behave in a similar fashion. HGMA1 and MDM2 can potentially serve as therapeutic targets or biomarkers for NFPA, whereas. Ki-67 is an important prognostic marker of NFPA progression. Additional studies with a larger study population are needed to confirm these findings.

\begin{abstract}
Acknowledgements This work were supported by the National High Technology Research and Development Program of China (863 Program) (2014AA020610), the Research Special Fund For Public Welfare Industry of Health (201402008), the National Natural Science Foundation of China (81271522), the Beijing Natural Science Foundation of China (7162035).
\end{abstract}

\section{Compliance with ethical Standards}

Conflict of interest The authors declare that they have no conflict of interest.

Open Access This article is distributed under the terms of the Creative Commons Attribution 4.0 International License (http:// creativecommons.org/licenses/by/4.0/), which permits unrestricted use, distribution, and reproduction in any medium, provided you give appropriate credit to the original author(s) and the source, provide a link to the Creative Commons license, and indicate if changes were made.

\section{References}

1. Giustina A (2012) Keep an eye on nonfunctioning pituitary adenomas. Clin Endocrinol 77(5):656-657 (2012). doi:10.1111/j.1365-2265.2012.04499.x

2. Cury ML, Fernandes JC, Machado HR, Elias LL, Moreira AC, Castro M (2009) Non-functioning pituitary adenomas: clinical feature, laboratorial and imaging assessment, therapeutic management and outcome. Arq Bras Endocrinol Metabol 53(1):31-39

3. Berkmann S, Schlaffer S, Nimsky C, Fahlbusch R, Buchfelder M (2014) Follow-up and long-term outcome of nonfunctioning pituitary adenoma operated by transsphenoidal surgery with intraoperative high-field magnetic resonance imaging. Acta Neurochir 156(12):2233-2243. doi:10.1007/s00701-014-2210-x

4. Rubinfeld H, Shimon I (2012) PI3K/Akt/mTOR and Raf/MEK/ ERK signaling pathways perturbations in non-functioning pituitary adenomas. Endocrine 42(2):285-291. doi:10.1007/ s12020-012-9682-3

5. Mohammed AA, Rotondo F, Munoz DG, Kovacs K, Bilbao JM, Karamchandani JR, Di Ieva A, Cusimano MD (2015) Diagnostic and prognostic biomarkers of a sellar melanocytic tumor mimicking pituitary adenoma: case report and literature review. Pathol Res Pract 211(9):682-687. doi:10.1016/j.prp.2015.04.005

6. Monsalves E, Larjani S, Loyola GB, Juraschka K, Carvalho F, Kucharczyk W, Kulkarni A, Mete O, Gentili F, Ezzat S, Zadeh G (2014) Growth patterns of pituitary adenomas and histopathological correlates. J Clin Endocrinol Metab 99(4):1330-1338. doi:10.1210/jc.2013-3054

7. Righi A, Morandi L, Leonardi E, Farnedi A, Marucci G, Sisto A, Frank G, Faustini-Fustini M, Zoli M, Mazzatenta D, Agati R, Foschini MP (2013) Galectin-3 expression in pituitary adenomas as a marker of aggressive behavior. Hum Pathol 44(11):2400 2409. doi:10.1016/j.humpath.2013.05.020

8. De Martino M, Forzati F, Arra C, Fusco A, Esposito F (2016) HMGA1-pseudogenes and cancer. Oncotarget. doi:10.18632/ oncotarget.7427

9. Fedele M, Fusco A (2010) HMGA and cancer. Biochim Biophys Acta 1799(1-2):48-54. doi:10.1016/j.bbagrm.2009.11.007

10. Liau SS, Whang E (2008) HMGA1 is a molecular determinant of chemoresistance to gemcitabine in pancreatic adenocarcinoma. Clin Cancer Res 14(5) 1470-1477. doi:10.1158/1078-0432. CCR-07-1450

11. Fedele M, Fusco A (2010) Role of the high mobility group A proteins in the regulation of pituitary cell cycle. J Mol Endocrinol 44(6):309-318. doi:10.1677/JME-09-0178

12. Fedele M, Visone R, De Martino I, Troncone G, Palmieri D, Battista S, Ciarmiello A, Pallante P, Arra C, Melillo RM, Helin K, Croce CM, Fusco A (2006) HMGA2 induces pituitary tumorigenesis by enhancing E2F1 activity. Cancer Cell 9(6):459-471. doi:10.1016/j.ccr.2006.04.024

13. Thayer KM, Beyer GA (2016) Energetic Landscape of MDM2p53 Interactions by computational mutagenesis of the MDM2p53 interaction. PLoS ONE 11(3):e147806. doi:10.1371/journal. pone.0147806

14. Haupt Y, Barak Y, Oren M (1996) Cell type-specific inhibition of p53-mediated apoptosis by mdm2. EMBO J 15(7):1596-1606

15. Lubet R, Wang Y, Zhang Z, You M (2005) Mouse models incorporating alterations in the major tumor suppressor genes P53 and P16: their use in screening for potential carcinogens, developing further relevant mouse models, and screening for potential chemopreventive and chemotherapetutic agents. Exp Lung Res 31(1):117-133

16. Rayburn E, Zhang R, He J, Wang H (2005) MDM2 and human malignancies: expression, clinical pathology, prognostic markers, and implications for chemotherapy. Curr Cancer Drug Targets 5(1):27-41

17. Mastronardi L, Guiducci A, Puzzilli F (2001) Lack of correlation between Ki-67 labelling index and tumor size of anterior pituitary adenomas. BMC Cancer 1:12

18. de Aguiar PH, Aires R, Laws ER, Isolan GR, Logullo A, Patil C, Katznelson L (2010) Labeling index in pituitary adenomas evaluated by means of MIB-1: is there a prognostic role? A critical review. Neurol Res 32(10):1060-1071. doi:10.1179/0161641 10X12670144737855

19. Salehi F, Agur A, Scheithauer BW, Kovacs K, Lloyd RV, Cusimano M (2009) Ki-67 in pituitary neoplasms: a reviewpart I. Neurosurgery 65(3):429-437. doi:10.1227/01. NEU.0000349930.66434.82 
20. Liu C, Gao H, Cao L, Gui S, Liu Q, Li C, Li D, Gong L, Zhang Y (2016) The role of FSCN1 in migration and invasion of pituitary adenomas. Mol Cell Endocrinol 419:217-224. doi:10.1016/j. mce.2015.10.021

21. Ferrante E, Ferraroni M, Castrignano T, Menicatti L, Anagni M, Reimondo G, Del MP, Bernasconi D, Loli P, Faustini-Fustini M, Borretta G, Terzolo M, Losa M, Morabito A, Spada A, Beck-Peccoz P, Lania AG (2006) Non-functioning pituitary adenoma database: a useful resource to improve the clinical management of pituitary tumors. Eur J Endocrinol 155(6):823-829. doi:10.1530/eje.1.02298

22. Nomikos P, Ladar C, Fahlbusch R, Buchfelder M (2004) Impact of primary surgery on pituitary function in patients with nonfunctioning pituitary adenomas:a study on 721 patients. Acta Neurochir 146(1):27-35. doi:10.1007/s00701-003-0174-3

23. Chen L, White WL, Spetzler RF, Xu B (2011) A prospective study of nonfunctioning pituitary adenomas: presentation, management, and clinical outcome. J Neurooncol 102(1):129-138. doi:10.1007/s11060-010-0302-X

24. Roelfsema F, Biermasz NR, Pereira AM (2012) Clinical factors involved in the recurrence of pituitary adenomas after surgical remission: a structured review and meta-analysis. Pituitary 15(1):71-83. doi:10.1007/s11102-011-0347-7

25. Qu X, Xu G, Qu Y, Song T (2011) The pseudocapsule surrounding a pituitary adenoma and its clinical significance. J Neurooncol 101(2):171-178. doi:10.1007/s11060-010-0247-0

26. Brochier S, Galland F, Kujas M, Parker F, Gaillard S, Raftopoulos C, Young J, Alexopoulou O, Maiter D, Chanson P (2010) Factors predicting relapse of nonfunctioning pituitary macroadenomas after neurosurgery: a study of 142 patients. Eur J Endocrinol 163(2):193-200. doi:10.1530/EJE-10-0255

27. Reeves R, Nissen MS (1990) The A.T-DNA-binding domain of mammalian high mobility group I chromosomal proteins. A novel peptide motif for recognizing DNA structure. J Biol Chem 265(15):8573-8582

28. Pallante P, Sepe R, Puca F, Fusco A (2015) High mobility group a proteins as tumor markers. Front Med 2:15. doi:10.3389/ fmed.2015.00015

29. De Martino I, Visone R, Wierinckx A, Palmieri D, Ferraro A, Cappabianca P, Chiappetta G, Forzati F, Lombardi G, Colao A, Trouillas J, Fedele M, Fusco A (2009) HMGA proteins upregulate $\mathrm{CCNB} 2$ gene in mouse and human pituitary adenomas. Cancer Res 69(5):1844-1850. doi:10.1158/0008-5472. CAN-08-4133

30. Šteňo A, Bocko J, Rychlý B, Chorváth M, Celec P, Fabian M, Belan V, Šteňo J (2014) Nonfunctioning pituitary adenomas: association of Ki-67 and HMGA-1 labeling indices with residual tumor growth. Acta Neurochir 156(3):451-461. doi:10.1007/ s00701-014-1993-0

31. Trapasso F, Sarti M, Cesari R, Yendamuri S, Dumon KR, Aqeilan RI, Pentimalli F, Infante L, Alder H, Abe N, Watanabe T, Viglietto G, Croce CM, Fusco A (2004) Therapy of human pancreatic carcinoma based on suppression of HMGA1 protein synthesis in preclinical models. Cancer Gene Ther 11(9):633-641. doi:10.1038/sj.cgt.7700745

32. Saeger W, Ludecke DK, Buchfelder M, Fahlbusch R, Quabbe HJ, Petersenn S (2007) Pathohistological classification of pituitary tumors: 10 years of experience with the German Pituitary Tumor Registry. Eur J Endocrinol 156(2):203-216. doi:10.1530/ eje.1.02326
33. Yildirim AE, Divanlioglu D, Nacar OA, Dursun E, Sahinoglu M, Unal T, Belen AD (2013) Incidence, hormonal distribution and postoperative follow up of atypical pituitary adenomas. Turk Neurosurg 23(2):226-231. doi:10.5137/1019-5149. JTN.6828-12.1

34. Zada G, Woodmansee WW, Ramkissoon S, Amadio J, Nose V, Laws EJ (2011) Atypical pituitary adenomas: incidence, clinical characteristics, and implications. J Neurosurg 114(2):336-344. doi: $10.3171 / 2010.8$.JNS10290

35. Righi A, Agati P, Sisto A, Frank G, Faustini-Fustini M, Agati R, Mazzatenta D, Farnedi A, Menetti F, Marucci G, Foschini MP (2012) A classification tree approach for pituitary adenomas. Hum Pathol 43(10):1627-1637 doi:10.1016/j. humpath.2011.12.003

36. Dubois, S., Guyetant, S., Menei, P., Rodien, P., Illouz, F., Vielle, B., Rohmer, V.: Relevance of Ki-67 and prognostic factors for recurrence/progression of gonadotropic adenomas after first surgery. EUR J ENDOCRINOL, 157(2), 141-147 (2007). doi:10.1530/EJE-07-0099

37. Micko, A.S.G., Wöhrer A, Wolfsberger S, Knosp E (2015) Invasion of the cavernous sinus space in pituitary adenomas: endoscopic verification and its correlation with an MRI-based classification. J NEUROSURG 122(4):803-811. doi:10.3171/2014.12. JNS141083

38. Chiloiro, S., Bianchi, A., Doglietto, F., de Waure, C., Giampietro, A., Fusco, A., Iacovazzo, D., Tartaglione, L., Di Nardo, F., Signorelli, F., Lauriola, L., Anile, C., Rindi, G., Maira, G., Pontecorvi, A., De Marinis, L.: Radically resected pituitary adenomas: prognostic role of $\mathrm{Ki} 67$ labeling index in a monocentric retrospective series and literature review. PITUITARY (2013). doi:10.1007/s11102-013-0500-6

39. Nag, S., Zhang, X., Srivenugopal, K.S., Wang, M.H., Wang, W., Zhang, R.: Targeting MDM2-p53 interaction for cancer therapy: are we there yet? CURR MED CHEM, 21(5), 553-574 (2014)

40. Urso L, Calabrese F, Favaretto A, Conte P, Pasello G (2016) Critical review about MDM2 in cancer: Possible role in malignant mesothelioma and implications for treatment. Crit Rev Oncol Hematol 97:220-230. doi:10.1016/j.critrevonc.2015.08.019

41. Momand J, Jung D, Wilczynski S, Niland J (1998) The MDM2 gene amplification database. Nucleic Acids Res 26(15):3453-3459

42. Mairinger FD, Walter RF, Ting S, Vollbrecht C, Kollmeier J, Griff S, Hager T, Mairinger T, Christoph DC, Theegarten D, Schmid KW, Wohlschlaeger J (2014) Mdm2 protein expression is strongly associated with survival in malignant pleural mesothelioma. Future Oncol 10(6):995-1005. doi:10.2217/fon.13.261

43. Zhao Y, Yu S, Sun W, Liu L, Lu J, McEachern D, Shargary S, Bernard D, Li X, Zhao T, Zou P, Sun D, Wang S (2013) A potent small-molecule inhibitor of the MDM2-p53 interaction (MI-888) achieved complete and durable tumor regression in mice. J Med Chem 56(13):5553-5561. doi:10.1021/jm4005708

44. Weinberg RA (1995) The retinoblastoma protein and cell cycle control. Cell 81(3):323-330

45. Indovina P, Pentimalli F, Casini N, Vocca I, Giordano A (2015) RB1 dual role in proliferation and apoptosis: cell fate control and implications for cancer therapy. Oncotarget 6(20):17873-17890. doi:10.18632/oncotarget.4286 